\title{
An unprotected conjugated linoleic acid supplement decreases milk production and secretion of milk components in grazing dairy ewes
}

\author{
D. E. Oliveira, ${ }^{\star 1}$ M. A. S. Gama, $\dagger$ D. Fernandes, ${ }^{*}$ L. O. Tedeschi, $\neq$ and D. E. Bauman $\S$ \\ *Department of Animal Science, Santa Catarina State University, Chapecó, Santa Catarina, 89802-200, Brazil \\ †Embrapa Dairy Cattle, Juiz de Fora, Minas Gerais, 36038-300, Brazil \\ fDepartment of Animal Science, Texas A\&M University, College Station 77843-2471 \\ §Department of Animal Science, Cornell University, Ithaca, NY 14853-0281
}

\begin{abstract}
Feeding conjugated linoleic acid (CLA) in a rumeninert form to dairy ewes has been shown to increase milk production, alter milk composition, and increase the milk fat CLA content. However, few studies have tested ruminally unprotected CLA sources. The objective of this study was to evaluate the effects of an unprotected CLA supplement (29.8\% of cis-9,trans-11 and $29.9 \%$ of trans-10,cis-12 isomers as methyl esters) on milk yield and composition of dairy ewes. Twenty-four lactating Lacaune ewes were used in a crossover design and received 2 dietary treatments: (1) control: basal diet containing no supplemental lipid and (2) basal diet plus CLA (30 g/d). The CLA supplement was mixed into the concentrate and fed in 2 equal meals after morning and afternoon milkings. Each experimental period consisted of $21 \mathrm{~d}$ : $7 \mathrm{~d}$ for adaptation and $14 \mathrm{~d}$ for data collection. The CLA supplement decreased milk fat content and yield by 31.3 and $38.0 \%$, respectively. Milk yield and secretion of milk lactose and protein were decreased by $8.0,9.8$, and $5.6 \%$, respectively. On the other hand, milk protein content and linear SCC score were 1.8 and $17.7 \%$ higher in ewes fed the CLA supplement. The concentration of milk fatty acids originating from de novo synthesis $(<\mathrm{C} 16)$ was decreased by $25 \%$, whereas the concentration of milk fatty acids taken up preformed from the plasma $(>\mathrm{C} 16)$ was increased by $22.6 \%$ in ewes fed the CLA supplement. The CLA supplement decreased C14:1/C14:0, C16:1/ C16:0, and C18:1/C18:0 desaturase indexes by 25, 18.7, and $0.1 \%$, respectively, but increased the cis-9,trans- 11 CLA/trans-11 C18:1 ratio by $8.6 \%$. The concentrations of trans-10,cis-12 CLA and cis-9,trans-11 CLA in milk fat was 309 and $33.4 \%$ higher in ewes fed CLA. Pronounced milk fat depression coupled with the deleterious effects on milk yield, milk SCC, and secretion of all milk solids observed in ewes fed an unprotected CLA
\end{abstract}

Received June 13, 2011.

Accepted September 30, 2011.

${ }^{1}$ Corresponding author: deolivei2@terra.com.br supplement is likely to be associated with high doses of trans-10, cis-12 CLA reaching the mammary gland, corroborating previous results obtained with dairy cows.

Key words: Lacaune ewe, mammary gland, milk fat depression, milk yield

\section{INTRODUCTION}

Conjugated linoleic acid (CLA) is a generic term used to describe a mixture of isomers of linoleic acid (C18:2 n-6) containing conjugated double bonds in their molecular structure. These compounds are mainly found in ruminant products as a consequence of partial ruminal hydrogenation of polyunsaturated FA present in feeds. More than 20 CLA isomers have been identified in ruminant milk fat, but cis-9,trans-11 CLA is by far the most abundant, usually representing 75 to $90 \%$ of total CLA in milk fat (Lock and Bauman, 2004). This isomer has been shown to possess health-enhancing properties such as anticarcinogenic and antidiabetogenic activities so that efforts have been made to increase milk CLA content (Parodi, 1997; Bauman et al., 2006). Initial attempts to achieve this goal were made by supplementing dairy cows with synthetically produced CLA, but the increase in milk fat CLA content was accompanied by an unexpected decrease in milk fat yield. This effect was subsequently shown to be caused by another CLA isomer present in the CLA supplement, trans-10, cis-12 CLA, which is a potent inhibitor of milk fat synthesis (Baumgard et al., 2000).

The methyl ester form of CLA (ME-CLA) has several advantages in commercial production as compared with the free FA form (Sæbø, 2003) and studies with dairy cows have indicated comparable results in terms of milk fat depression (MFD; de Veth et al., 2004; Perfield et al., 2004). Just as occurs with esterified FA in dietary lipids, the methyl esters of FA are hydrolyzed by bacterial lipases and biohydrogenated by rumen bacteria (Maia et al., 2010). Therefore, lipid encapsulation of ME-CLA has been used as a rumen protection method that offers partial protection against biohydrogenation that is comparable to other rumen 
protection methods for CLA (Perfield et al., 2004). Thus, investigations of CLA effects in dairy cows have often used lipid encapsulated ME-CLA (e.g., de Veth et al., 2006; Castañeda-Gutiérrez et al., 2007; von Soosten et al., 2011).

The antilipogenic effect of trans-10,cis-12 CLA has been observed in lactating small ruminants in which goats (Lock et al., 2008; Shingfield et al., 2009) were apparently less responsive than cows (de Veth et al., 2004) and ewes (Lock et al., 2006; Sinclair et al., 2007, 2010). Of note, supplements containing trans-10,cis-12 CLA can be used strategically to improve energy balance of lactating animals by decreasing their energy requirements for milk synthesis. Depending on the physiological status of the animal, the energy spared for milk fat synthesis could be directed to milk production or secretion of other milk components such as protein (Bernal-Santos et al., 2003; Mackle et al., 2003; Odens et al., 2007; Medeiros et al., 2010). Feeding a lipid-encapsulated supplement that contained ME of trans-10,cis-12 CLA was shown to increase both milk production and milk CLA content in dairy ewes (Lock et al., 2006). However, as reviewed by Chilliard et al. (2003) and Shingfield et al. (2010), the rumen metabolism of lipid supplements differs in small ruminants as compared with dairy cows, and we know of no studies that have evaluated the effects of unprotected CLA supplements on milk yield and composition of dairy ewes. The objective of this study was to evaluate the effects of an unprotected ME-CLA supplement on milk yield, milk composition, and the milk FA profile of Lacaune dairy ewes.

\section{MATERIALS AND METHODS}

\section{Animals, Treatments, and Experimental Procedures}

Animal Care and Handling procedures were followed according to the Santa Catarina State University Ethical Committee. Twenty-four Lacaune ewes (40 to 70 DIM) were paired by BW, parity, and previous milk production, and randomly assigned to the following dietary treatments in a crossover design: (1) basal diet containing no supplemental lipid (control, CON) and (2) basal diet plus $30 \mathrm{~g} / \mathrm{d}$ of an unprotected ME-CLA supplement. Each experimental period lasted $21 \mathrm{~d}(7 \mathrm{~d}$ for adaptation and $14 \mathrm{~d}$ for data collection), and experimental periods were separated by a washout interval in which animals were fed the CON diet for $7 \mathrm{~d}$ to minimize any carryover effect (Baumgard et al., 2000). Data from 2 ewes were not included in the analyses: 1 ewe on the CLA diet stopped producing milk over the first week during the CLA treatment and 1 ewe fed the CON diet became lame due to hoof problems.
Ewes were fed $1.2 \mathrm{~kg} / \mathrm{d}$ (DM basis) of a concentrate mixture according to the NRC (2007) to complement the estimated nutrient intake coming from forage and formulated using the Small Ruminant Nutrition System (SRNS; Tedeschi et al., 2010). The concentrate contained ground corn (56\%), soybean meal (40\%), and a commercial vitamin-mineral mix (4\%), and it was individually fed twice daily $(0.6 \mathrm{~kg} / \mathrm{meal})$ after the morning and afternoon milkings (Table 1). The unprotected CLA supplement (Luta-60; BASF AG, São Paulo, Brazil) consisted of FA methyl esters (FAME) with the following composition: $4.1 \%$ palmitic acid, $3.6 \%$ stearic acid, $27.4 \%$ oleic acid, $1.2 \%$ linoleic acid, $29.8 \%$ cis-9,trans-11 CLA, $29.9 \%$ trans-10, cis-12 CLA, and $3.0 \%$ other FA. This CLA supplement was mixed into the concentrate twice daily $(15 \mathrm{~g} / \mathrm{meal})$ to minimize refusals; therefore, each ewe received about $9 \mathrm{~g} / \mathrm{d}$ of trans-10,cis-12 CLA via the concentrate. The extent to which the unprotected CLA supplement would be biohydrogenated was unknown, so the dose was chosen based on the assumption that biohydrogenation would be extensive (more than 90\%, Jenkins et al., 2008) with only a small percent escaping and being available for absorption in the small intestine. All ewes rotationally grazed 3 paddocks of annual ryegrass and white clover (50:50) with free access to fresh water. A mineral salt and vitamin supplement was also available free choice in all paddocks. After the first milking at $0500 \mathrm{~h}$, the ewes were individually fed $0.6 \mathrm{~kg}$ of the daily concentrate and returned to pasture. At $1130 \mathrm{~h}$, animals were brought from pasture to a barn and were individually fed $2.5 \mathrm{~kg}$ of corn silage (as-fed basis) until the afternoon milking at $1700 \mathrm{~h}$. Orts were weighed daily to calculate silage intake. After the afternoon milking, the ewes were fed the remaining $0.6 \mathrm{~kg}$ of concentrate and subsequently returned to pasture. The BW was recorded at the beginning and at the end of each experimental period.

\section{Milk Production and Composition}

The individual milk yield was recorded daily in line meters (Ordemilk Ltda., Treze Tílias, Santa Catarina, Brazil) throughout the study in a milking parlor designed for ewes. Milk samples were taken at each milking during the collection period, pooled by day and stored at $4^{\circ} \mathrm{C}$ with a preservative (bromopol tablet; D \& F Control Systems Inc., San Ramon, CA) before being analyzed for components (fat, protein, lactose, and TS) and SCC using infrared analysis (AOAC, 2000; method \#972.160). Additional milk samples were also collected the same way throughout each collecting period and frozen at $-20^{\circ} \mathrm{C}$ without preservative and stored for subsequent FA profile analysis. 
Table 1. Ingredient composition of concentrate and chemical composition of forages and concentrate

\begin{tabular}{lccc}
\hline Composition & Concentrate $^{1}$ & Pasture & Corn silage \\
\hline Ingredient, \% & 56 & & \\
Corn, ground & 40 & & \\
Soybean meal & 4 & & \\
Mineral and vitamin mix $^{2}$ & & & \\
Chemical & 92.2 & 18.3 & 32.3 \\
DM, \% & 19.5 & 5.5 & 8.9 \\
CP, \% DM & 17.7 & 26.9 & 49.2 \\
NDF, \% of DM & 6.5 & 5.7 & 1.9 \\
ADF, \% of DM & 2.3 & & \\
Lignin, \% of DM &
\end{tabular}

${ }^{1}$ Does not include the conjugated linoleic acid (CLA) supplement. The analyzed fatty acid composition of the unprotected CLA supplement was 0.1\% C14:0; 4.1\% C16:0; 0.1\% C16:1; 3.6\% C18:0; $27.4 \%$ C18:1; $1.2 \%$ C18:2 cis-9,cis-12; 29.8\% CLA cis-9,trans-11; and 29.9\% CLA trans-10,cis-12.

${ }^{2}$ Sheep mineral and vitamin premix (Nutrimasa Agroindustrial Feeds, Chapecó, Brazil). Major minerals (g/kg) were Ca, 190; Na, 35; Mg, 30; S, 18; and P, 69. Trace minerals (mg/kg) were Zn, 1,440; Fe, 840; Mn, 1,550; Co, 3.4; and Se, 22. Vitamins (IU $/ \mathrm{kg}$ ) were vitamin A, 125; vitamin $\mathrm{D}_{3}, 10$; and vitamin $\mathrm{E}, 500$.

\section{Plasma Metabolite Analysis}

Blood samples from the jugular vein were collected in 5-mL Vacutainer tubes (Zhejiang Kangshi Medical Devices Co., Hangzhou, China) containing EDTA after the afternoon milking on d 21 of each experimental period and immediately placed on ice before centrifugation. Plasma obtained after centrifugation $(2,800 \times g$, $15 \mathrm{~min}$ ) was stored at $-20^{\circ} \mathrm{C}$ for glucose, insulin, and NEFA analyses. The concentration of NEFA was determined by a colorimetric-enzymatic method (NEFA C; Wako Pure Chemical Industries, Osaka, Japan) using 96-well ELISA microplates. Glucose analysis was performed by direct reading (glucose oxidase enzyme immobilized in membrane) on a YSI 2700 Select autoanalyzer (biochemistry analyzer; Yellow Springs Instrument Co. Inc., Yellow Springs, $\mathrm{OH}$ ) and insulin by RIA (TECSA, Tecnologia em Sanidade Animal, Belo Horizonte, Minas Gerais, Brazil).

\section{Chemical Analysis}

Samples of pasture, silage, and concentrate were analyzed according to AOAC (2000) for DM (method \#934.01) and CP (method \#988.05), whereas NDF, ADF, NDIN, ADIN, and lignin contents were determined according to Van Soest et al. (1991). Determination of NDF content in silage was performed using heat-stable $\alpha$-amylase and corrected for ash content.

Milk fat was extracted according to Hara and Radin (1978) using a 3:2 (vol/vol) mixture of hexane and isopropanol $(18 \mathrm{~mL} / \mathrm{g}$ of fat cake) followed by a $67 \mathrm{~g} / \mathrm{L}$ of sodium sulfate solution (12 mL/g of fat cake). The fat cake was previously obtained by milk centrifugation at $17,800 \times g$ for $30 \mathrm{~min}$ at $8^{\circ} \mathrm{C}$. Milk FAME were obtained by base-catalyzed transmethylation using a freshly prepared methylation reagent $(0.4 \mathrm{~mL}$ of $5.4 \mathrm{~mol} / \mathrm{L}$ of sodium methoxide solution $+1.75 \mathrm{~mL}$ of methanol) according to Christie (1982) with modifications (Chouinard et al., 1999). The mixture was neutralized with oxalic acid ( $1 \mathrm{~g}$ of oxalic acid in $30 \mathrm{~mL}$ of diethyl ether) and calcium chloride was added to remove methanol residues. The FAME were determined by GC (model 6890 N; Agilent Technologies Brasil Ltda., Barueri, São Paulo, Brazil) fitted with a flame-ionization detector and equipped with a CP-Sil 88 fused-silica capillary column $(100 \mathrm{~m} \times 0.25 \mathrm{~mm} \times 0.2 \mu \mathrm{m}$ film thickness; Varian Inc., Mississauga, ON). Operating conditions included injector and detector temperatures both at $250^{\circ} \mathrm{C}, \mathrm{H}_{2}$ as carrier gas $(1 \mathrm{~mL} / \mathrm{min})$, and for the flame-ionization detector (35 mL/min), $\mathrm{N}_{2}$ as makeup gas $(30 \mathrm{~mL} / \mathrm{min})$, and purified air $(286 \mathrm{~mL} / \mathrm{min})$. The initial temperature was $45^{\circ} \mathrm{C}$ and held for $4 \mathrm{~min}$, increased by $13^{\circ} \mathrm{C} / \mathrm{min}$ to $175^{\circ} \mathrm{C}$ and held for $27 \mathrm{~min}$, and increased by $4^{\circ} \mathrm{C} / \mathrm{min}$ to $215^{\circ} \mathrm{C}$ and held for 35 min (Cruz-Hernandez et al., 2007). The FAME were identified by comparison with 3 reference FAME standards (Supelco37 mix \#47885$\mathrm{U}$, linoleic acid isomers mix \#47791, and CLA isomers mix \#05632; Sigma-Aldrich, St. Louis, MO), as described by Kramer et al. (2001) and Cruz-Hernandez et al. (2007). The GC run was interrupted after elution of the trans-10,cis-12 CLA peak because FA eluting after the trans-10,cis-12 CLA isomer were assumed to be of little importance for the purpose of the present study. The transfer of cis-9,trans-11 CLA and trans-10,cis-12 CLA from the dietary supplement to milk fat were also calculated. This involved a comparison of the incremental difference in the daily secretion of each CLA isomer in milk fat during the CLA supplementation period and the control period and then dividing the increment difference by the daily intake of each CLA isomer provided by the CLA supplement. 
Table 2. Milk yield, milk composition, SCC, and BW of dairy ewes fed a control (CON) or conjugated linoleic acid (CLA)-supplemented diet

\begin{tabular}{lcccc}
\hline & \multicolumn{2}{c}{ Treatment } & & \\
\cline { 2 - 3 } Variable & CON $^{1}$ & CLA supplement & & \\
\hline Milk yield, $\mathrm{kg} / \mathrm{d}$ & 1.88 & 1.73 & $\mathrm{SE}$ & $P$-value \\
Fat content, \% & 5.62 & 3.86 & 0.08 & $<0.01$ \\
Protein content, $\%$ & 4.91 & 5.00 & 0.15 & $<0.01$ \\
Lactose content, \% & 4.55 & 4.48 & 0.06 & $<0.01$ \\
Fat yield, g/d & 106.1 & 65.8 & 0.06 & $<0.01$ \\
Protein yield, g/d & 91.5 & 86.4 & 0.004 & $<0.01$ \\
Lactose yield, g/d & 86.3 & 77.8 & 0.003 & $<0.01$ \\
Log SCC & 3.34 & 3.93 & 0.004 & $<0.01$ \\
BW, $\mathrm{kg}$ & 59.5 & 59.7 & 0.25 & $<0.01$ \\
ADG, $\mathrm{kg} / \mathrm{d}$ & 0.22 & 0.25 & 0.02 & 0.51 \\
\hline
\end{tabular}

${ }^{1}$ Control diet (no supplemental lipid added).

${ }^{2}$ Supplement: $30 \mathrm{~g} / \mathrm{d}$ of an unprotected CLA supplement.

\section{Statistical Analysis}

Data were analyzed in a crossover design using the PROC MIXED of the SAS statistical package (SAS Inst. Inc., Cary, NC). The effects of sequence (CON to CLA supplement or CLA supplement to CON) and treatments (CON or CLA supplement) were assigned as fixed factors and the effects of period (1 or 2) and animal within sequence were assumed to be random factors, as indicated by Kuehl (2000), except that no carryover effect was accounted for (not enough degrees of freedom). The least squares means was used to determine the treatment effect. For temporal analyses (e.g., milk yield and milk components), a repeated measure design was used using the PROC MIXED of the SAS statistical package (SAS Inst. Inc.), assuming animal within sequence as the subject of the RANDOM statement. The auto-regressive 1 was used for the variance(co) variance matrix because it provided the lowest Akaike information criterion (AIC).

\section{RESULTS}

Consumption of concentrate containing CLA and corn silage was complete for all animals. Performance and milk composition of ewes fed the CON or CLA supplement are shown in Table 2, and the pattern of temporal changes in milk yield and milk components for both treatments is depicted in Figures 1 and 2. The CLA supplement dramatically decreased the milk fat content $(31.3 \%)$ and milk fat yield $(38.0 \%)$ compared with the CON. Milk yield, milk lactose content, milk lactose yield, and milk protein yield were also decreased by $8.0,1.5,9.8$, and $5.6 \%$ in CLA-fed ewes, respectively (Table 2). The CLA supplement increased milk protein content (Figure 2) and milk SCC by 1.8 and $17.7 \%$, respectively. The BW and ADG were unaffected by the CLA supplement.

Concentrations of FA in the milk fat from ewes fed the CON or CLA supplement are presented in Table 3. The CLA supplement increased C18:0, C18:1 cis-9, and C20:0 in milk fat by $32.4,8.1$, and $17.6 \%$, respectively. Trans C18:1 isomers from trans-5 to trans- 14 were increased, whereas concentrations of C12:0, C14:1 cis-9, and $\mathrm{C} 16: 1$ cis-9 were decreased by $35.1,28.1$, and $19.3 \%$, respectively, in milk fat from ewes fed the CLA supplement. Concentrations of milk FA originating from de novo synthesis $(<\mathrm{C} 16)$ were decreased by $25 \%$ in ewes fed the CLA supplement. In contrast, concentrations of milk FA taken up preformed from the blood stream (>C16) were increased by $22.6 \%$ in ewes fed the CLA supplement. The CLA supplement decreased C14:1/ C14:0 and $\mathrm{C} 16: 1 / \mathrm{C} 16: 0$ desaturase indexes by 25.0 and $18.7 \%$, respectively, but increased the cis-9,trans- 11 CLA/trans-11 C18:1 index by $8.6 \%$. In contrast, C18:1/ C18:0 was relatively unaffected $(0.1 \%$ decrease)

Concentrations of trans-10,cis-12 CLA and cis9,trans-11 CLA in milk fat were 309 and $33.4 \%$ higher, respectively, in ewes fed the CLA supplement. However, the proportion of the supplement transferred to milk fat was similar for the 2 CLA isomers. The transfer efficiency of trans-10,cis-12 CLA from diet to milk (proportion of trans-10,cis-12 CLA provided by the dietary CLA supplement that was secreted in milk fat) was 3.2 $\pm 0.6 \%$ (mean $\pm \mathrm{SE}$ ) in ewes fed the CLA supplement. Likewise, the efficiency of transfer of cis-9,trans-11 CLA from the dietary CLA supplement to secretion in milk fat averaged $3.1 \pm 2.3 \%$. Plasma concentrations of NEFA, glucose, and insulin in blood were unaffected by the CLA supplement (Table 4). Milk secretion of fatty acids derived from both de novo and preformed sources was decreased in ewes fed the CLA supplement, 
(A)

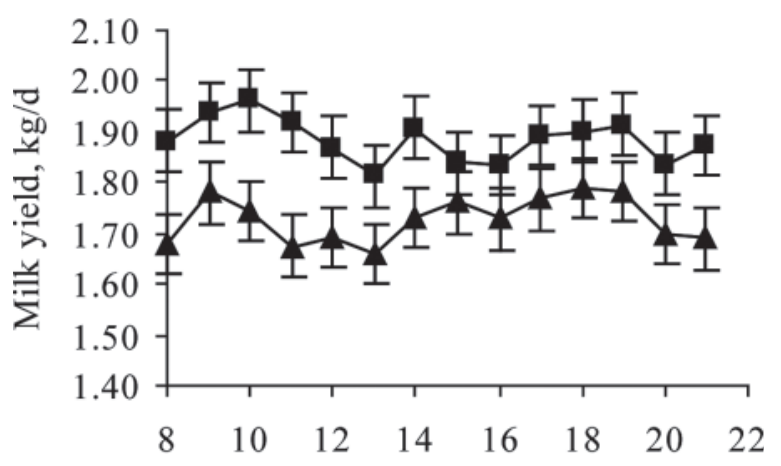

(B)

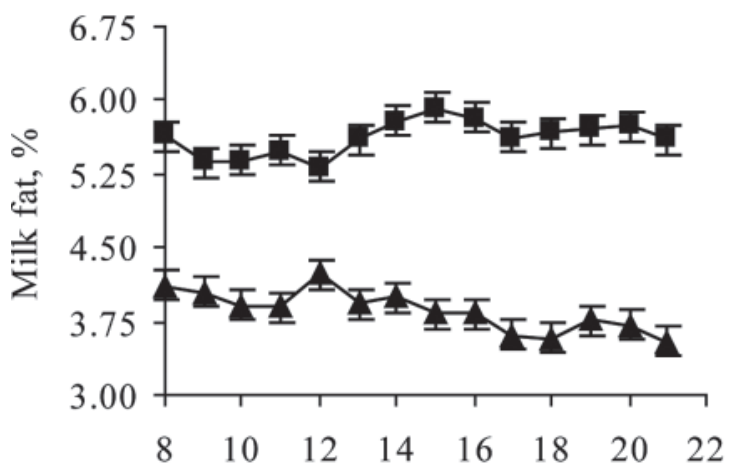

(C)

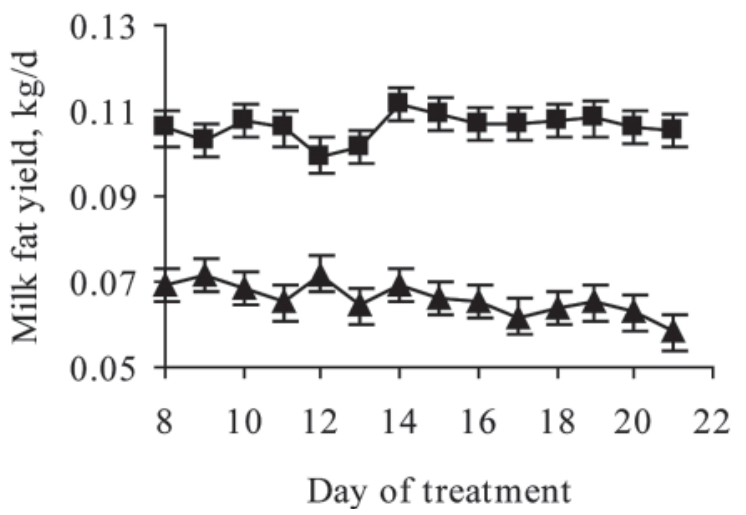

Figure 1. Variation in milk yield (A), milk fat content (B), and milk fat yield, (C) of ewes fed a control $(\mathbf{\square} ; \mathrm{n}=11)$ or conjugated linoleic acid (CLA)-supplemented diet $(\mathbf{\Delta} ; \mathrm{n}=11)$. The standard error is indicated by the error bars over each point.

although the magnitude of the response was higher for the former (Figure 3).

\section{DISCUSSION}

Earlier studies have observed that a CLA supplement containing trans-10, cis-12 CLA resulted in a decrease in milk fat secretion in sheep, goats, and cows and this has been generally accompanied by either no change or an increase in milk yield (see reviews by Bauman et al., 2008; Harvatine et al., 2009). In the present study, the CLA-supplemented ewes produced less milk throughout the treatment period (Figure 1A). This difference may relate to CLA dose, as the increase in milk fat content of trans-10, cis-12 CLA and the decrease in milk fat content and yield observed in ewes fed CLA in this study (Tables 2 and 3 and Figures $1 \mathrm{~B}$ and $1 \mathrm{C}$ ) was more pronounced than expected based on previous studies with lactating ewes in which a lipid-encapsulated CLA supplement was used (Lock et al., 2006; Sinclair et al., 2007, 2010). The magnitude of this effect was even greater in 1 CLA-treated ewe, which stopped producing milk during the first week of the treatment period (see Materials and Methods section). Such a pronounced MFD in response to CLA was unexpected because we used an unprotected CLA supplement. Figures $1 \mathrm{~B}$ and $1 \mathrm{C}$ show that from the first day until the last day of milk sampling ( $\mathrm{d} 8$ to 21 of treatment), the decreases in milk fat content and yield were consistent probably because the CLA was being fed for $7 \mathrm{~d}$ before the first sampling. We used this sampling schedule because we were not expecting this significant effect because the CLA source was unprotected from ruminal metabolism.

In choosing a CLA dose, we assumed that biohydrogenation of the unprotected CLA would be extensive and estimated that approximately $0.4 \mathrm{~g} / \mathrm{d}$ of trans10,cis-12 (Lock et al., 2006) would be delivered into the abomasum of the ewes if rumen biohydrogenation was $95 \%$. Using Equation 5 in the paper of de Veth et al. (2004), which correlates the abomasal dose of trans10,cis-12 CLA to the amount of trans-10,cis-12 CLA secreted in milk, we estimated that about $6 \%$ of the dietary trans-10, cis-12 CLA escaped ruminal biohydrogenation $(0.52 \mathrm{~g} / \mathrm{d}$ of trans-10, cis-12 CLA). Additionally, using a proportional dose of trans-10,cis-12 CLA on a metabolic weight basis to compare our data with those reported by de Veth et al. (2004), an equivalent milk fat yield reduction was found in ewes and cows (37.90 vs. $37.40 \%$, respectively).

Although investigations of the effect of fat supplements in small ruminants has been less extensive than for dairy cows, reviews by Chilliard et al. (2003) and Shingfield et al. (2010) highlight that studies to date indicate considerable differences. For example, the occurrence of MFD is not common in small ruminants even when plant oils or marine oils are fed. Possible reasons to explain the differences in the response of small ruminants to fat supplementation have been suggested, but the lack of information makes it difficult to identify the basis of the mechanisms (Chilliard et al., 2003; Shingfield et al., 2010). Nevertheless, the results 
from the present study suggest that the magnitude of trans-10,cis-12 CLA-induced MFD in lactating ewes is similar to that observed in dairy cows on a metabolic weight basis.

Trans-10,cis-12 CLA inhibits the activity and gene expression for $\Delta^{9}$-desaturase in the mammary gland and, as a consequence, reductions in the desaturase indexes have been characteristically observed for milk fat from trans-10,cis-12-treated ruminants (Bauman et al., 2008; Harvatine et al., 2009). In the present study, a decrease occurred for the ratio of $\mathrm{C} 14: 1 / \mathrm{C} 14: 0$ and C16:1/C16 in milk fat. However, milk fat content of trans $\mathrm{C} 18: 1 \mathrm{FA}$ was also increased in CLA-supplemented ewes, consistent with partial biohydrogenation of the CLA in the rumen, and increase in mammary uptake of trans C18:1 is undoubtedly the reason for the small change in the desaturase index for $\mathrm{C} 18: 1 / \mathrm{C} 18: 0$. The higher CLA/trans-11 C18:1 ratio observed in milk fat from ewes fed CLA is consistent with the increased mammary uptake of cis-9,trans-11 CLA coming from the dietary supplement. There were no effects of the CLA supplement on plasma concentrations of NEFA, glucose, or insulin (Table 4), and this is similar to observations with CLA-treated dairy cows, which is in agreement with the review of Bauman et al. (2011).

In MFD induced by low doses of trans-10, cis-12 CLA and diet-induced MFD, effects are specific for milk fat and appear to be regulated by the sterol response element-binding protein (SREBP) transcription factor family (Bauman et al., 2011). The SREBP are global regulators of lipid metabolism, and in these MFD situations, a downregulation of SREBP-1c occurs, which corresponds to a coordinated decrease in the mRNA abundance for key lipogenic enzymes in the mammary synthesis of milk fat (Harvatine and Bauman, 2006; Gervais et al., 2009). Thus, milk fat output is decreased, but the secretion of milk, milk protein, and milk lactose is generally unaffected, although in some cases, when nutrient intake is marginal, the decrease in nutrient use for milk fat synthesis allows for an increase in production of milk and milk protein (Bernal-Santos et al., 2003; Mackle et al., 2003; Odens et al., 2007; Medeiros et al., 2010). In contrast, a decrease in milk production has been reported at higher doses of CLA. Chouinard et al. (1999) abomasally infused different doses of a commercial CLA mixture in cows and observed a $14.9 \%$ decrease in milk yield at the highest dose $(31.1 \mathrm{~g} / \mathrm{d}$ of trans-10, cis-12). Similarly, Baumgard et al. (2002) observed a $14.1 \%$ decrease in milk yield when dairy cows were abomasally infused with $13.6 \mathrm{~g} / \mathrm{d}$ of trans-10, cis-12 CLA. The most striking example was the study by Bell and Kennelly (2003), where abomasal infusion of a high dose of CLA ( $46 \mathrm{~g} / \mathrm{d}$ of trans-10, cis-12 CLA) resulted in a $38 \%$ decrease in milk production as
(A)

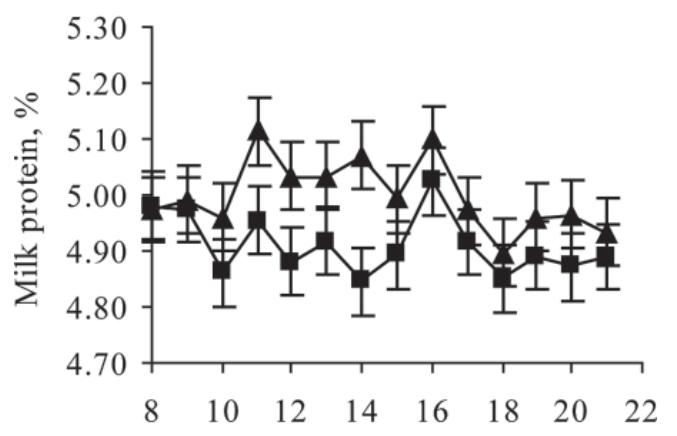

(B)

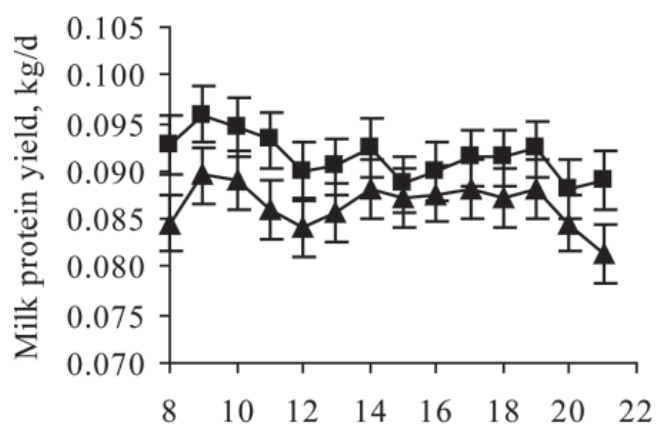

(C)

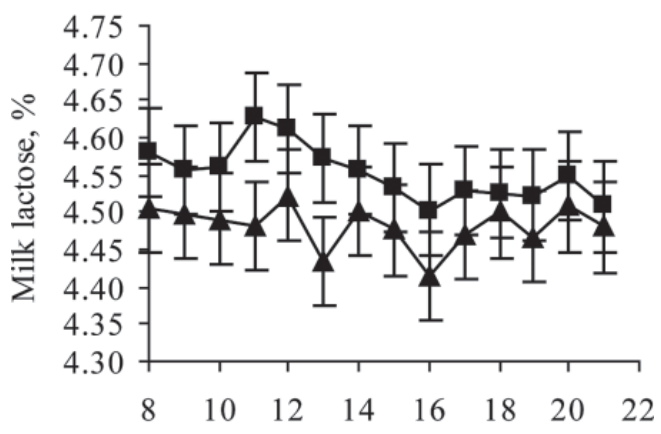

(D)

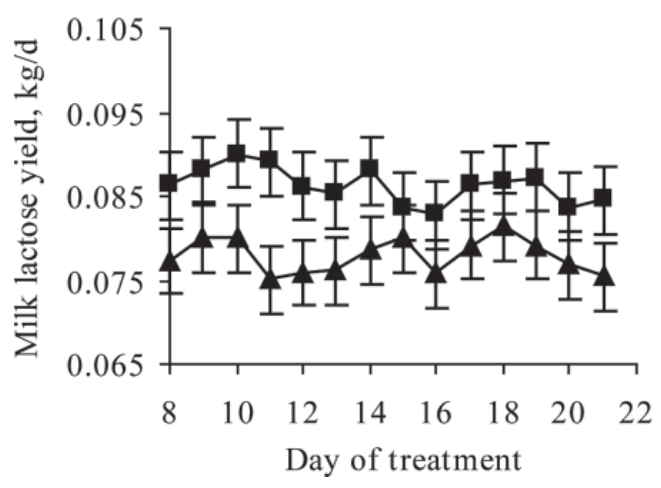

Figure 2. Variation in milk protein content (A), milk protein yield (B), milk lactose content (C), and milk lactose yield (D) of ewes fed a control $(\mathbf{\square} ; \mathrm{n}=11)$ or conjugated linoleic acid (CLA)-supplemented $\operatorname{diet}(\mathbf{\Lambda} ; \mathrm{n}=11)$. The standard error is indicated by the error bars over each point. 
Table 3. Fatty acid profile from milk of ewes fed a control or conjugated linoleic acid (CLA)-supplemented $\operatorname{diet}^{1}$

\begin{tabular}{|c|c|c|c|c|}
\hline \multirow[b]{2}{*}{$\begin{array}{l}\text { Fatty acid, } \\
\mathrm{g} / 100 \mathrm{~g} \text { of fat }\end{array}$} & \multicolumn{2}{|c|}{ Treatment } & \multirow[b]{2}{*}{ SEM } & \multirow[b]{2}{*}{$P$-value } \\
\hline & Control & $\begin{array}{c}\text { CLA } \\
\text { supplement }\end{array}$ & & \\
\hline C4:0 & 3.45 & 3.31 & 0.10 & 0.35 \\
\hline C6:0 & 2.53 & 1.45 & 0.05 & 0.0001 \\
\hline C8:0 & 2.42 & 1.22 & 0.05 & 0.0001 \\
\hline C10:0 & 8.12 & 4.14 & 0.21 & 0.0001 \\
\hline C12:0 & 5.00 & 3.25 & 0.19 & 0.0001 \\
\hline C14:0 & 10.95 & 10.79 & 0.46 & 0.63 \\
\hline C14:1 cis-9 & 0.18 & 0.13 & 0.03 & 0.0001 \\
\hline C15:0 & 0.98 & 0.93 & 0.03 & 0.32 \\
\hline C16:0 & 24.51 & 24.00 & 0.66 & 0.18 \\
\hline C16:1 cis-9 & 0.81 & 0.65 & 0.08 & 0.0002 \\
\hline C17:0 & 0.46 & 0.51 & 0.02 & 0.01 \\
\hline C18:0 & 10.03 & 13.28 & 1.22 & 0.0001 \\
\hline C18:1 trans-4 & 0.02 & 0.07 & 0.02 & 0.13 \\
\hline C18:1 trans-5 & 0.02 & 0.04 & 0.003 & 0.0001 \\
\hline $\mathrm{C} 18: 1$ trans $-6+$ trans $-7+$ trans -8 & 0.16 & 0.29 & 0.02 & 0.0001 \\
\hline C18:1 trans-9 & 0.243 & 0.38 & 0.02 & 0.0001 \\
\hline C18:1 trans-10 & 0.34 & 0.90 & 0.09 & 0.0001 \\
\hline C18:1 trans-11 & 1.55 & 2.38 & 0.17 & 0.0001 \\
\hline C18:1 trans-12 & 0.35 & 0.62 & 0.04 & 0.0001 \\
\hline C18:1 trans -13 + trans -14 & 0.47 & 0.81 & 0.02 & 0.0001 \\
\hline $\mathrm{C} 18: 1$ cis $-9+$ trans -15 & 14.98 & 16.17 & 0.77 & 0.005 \\
\hline C18:2 cis- 9 , cis-12 & 1.99 & 1.98 & 0.08 & 0.92 \\
\hline C20:0 & 0.18 & 0.21 & 0.02 & 0.0001 \\
\hline C18:3 cis-9, cis-12, cis-15 & 0.44 & 0.42 & 0.04 & 0.34 \\
\hline C18:2 cis-9,trans-11 CLA & 0.80 & 1.07 & 0.10 & 0.0001 \\
\hline C18:2 trans-10, cis-12 CLA & 0.07 & 0.28 & 0.01 & 0.0001 \\
\hline Unknowns & 8.95 & 10.72 & - & - \\
\hline \multicolumn{5}{|l|}{ Summation } \\
\hline$<\mathrm{C} 16$ & 33.65 & 25.24 & 0.84 & 0.0001 \\
\hline $\mathrm{C} 16: 0$ and $\mathrm{C} 16: 1$ cis-9 & 25.33 & 24.66 & 0.69 & 0.08 \\
\hline$>\mathrm{C} 16$ & 30.21 & 37.02 & 1.66 & 0.0001 \\
\hline \multicolumn{5}{|l|}{ Desaturase index } \\
\hline $\mathrm{C} 14: 1 / \mathrm{C} 14+\mathrm{C} 14: 1$ & 0.02 & 0.01 & 0.002 & 0.0001 \\
\hline $\mathrm{C} 16: 1 / \mathrm{C} 16+\mathrm{C} 16: 1$ & 0.032 & 0.026 & 0.001 & 0.004 \\
\hline $\mathrm{C} 18: 1 / \mathrm{C} 18+\mathrm{C} 18: 1$ & 1.00 & 0.98 & 0.0002 & 0.001 \\
\hline $\begin{array}{l}\text { cis-9,trans-11 CLA/C18:1 } \\
\text { trans- } 11+\text { cis- } 9, \text { trans- } 11 \text { CLA }\end{array}$ & 2.79 & 3.06 & 0.37 & 0.0006 \\
\hline
\end{tabular}

${ }^{1}$ The GC run was interrupted after elution of the trans-10, cis-12 CLA peak because fatty acids eluting after the trans-10,cis-12 CLA isomer were assumed to be of little importance for the purpose of the present study.

well as decreases in the secretion of milk fat (57\%), lactose $(47 \%)$, and protein $(13 \%)$.

Consistent with differences in milk phenotype, the mechanism whereby high CLA doses affect mammary metabolism appears to differ. Bell and Kennelly (2003) reported that, in addition to the decrease in the production of milk and milk components, they observed an increase in milk SCC that was reversible and not associ- ated with mastitis incidence or a change in milk bacterial count. Based on this, they suggested the mechanism involved apoptosis and the involution of mammary epithelial cells. More recently, Keating et al. (2008) conducted an in vitro study using mammary epithelial cells and showed that high doses of both cis-9,trans-11 and trans-10,cis-12 CLA isomers are deleterious to the mammary gland, decreasing cell growth and increasing

Table 4. Concentrations of NEFA, glucose, and insulin in plasma of ewes fed a control or conjugated linoleic acid (CLA)-supplemented diet

\begin{tabular}{|c|c|c|c|c|}
\hline Metabolite & Control & $\begin{array}{c}\text { CLA } \\
\text { supplement }\end{array}$ & SEM & $P$-value \\
\hline $\mathrm{NEFA}, \mu \mathrm{mol} / \mathrm{L}$ & 130.0 & 140.0 & 7.0 & 0.84 \\
\hline Glucose, $\mathrm{mg} / \mathrm{L}$ & 644.0 & 672.1 & 25.8 & 0.25 \\
\hline Insulin, $\mu \mathrm{IU} / \mathrm{mL}$ & 5.47 & 5.67 & 1.91 & 0.89 \\
\hline
\end{tabular}




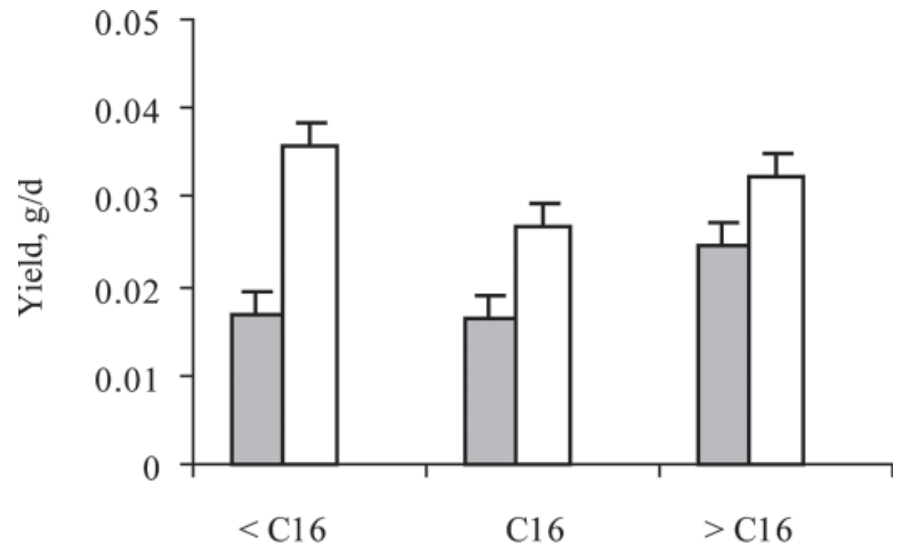

Milk fatty acids

Figure 3. Milk fatty acids yield in a daily basis in ewes fed a control $(\mathrm{n}=11$, open bar) or conjugated linoleic acid (CLA)-supplemented diet $(\mathrm{n}=11$, gray bar). Fatty acids are categorized according to origin: $<\mathrm{C} 16$ are from de novo synthesis fatty acids, $>$ C16 represent preformed fatty acids taken up from the bloodstream, and C16 fatty acids are derived from both sources. The standard error is indicated by error bars over each column. $P<0.001$.

apoptosis. In the present study with lactating ewes, the level of CLA supplementation resulted in a relatively high concentration of trans-10,cis-12 CLA in milk fat (Table 3) and this corresponded to a decrease in the production of milk; significant decreases in the secretion of milk fat, lactose, and protein; and an increase in milk SCC (Table 2). Although not as dramatic as reported by Bell and Kennelly (2003), the pattern of change in the secretion of milk components and the increase in SCC would be consistent with a mechanism involving apoptosis and involution of mammary epithelial cells, as suggested by these workers.

Supplements of trans-10,cis-12 CLA also decrease body fat in growing animals and several mechanisms for the anti-obesity effect have been purposed (Kennedy et al., 2010). Results indicate that high doses of trans10, cis- 12 ( 0.5 to $>1.0 \%$ of the diet) dramatically reduce adipose tissue and induce inflammation responses, insulin resistance, and hepatic steatosis (TsuboyamaKasaoka et al., 2000; Poirier et al., 2006). However, recent studies have shown this is a dose-response effect and that low doses of trans-10,cis-12 CLA were effective in reducing adipose tissue in growing mice without the off-target induction of inflammation, insulin resistance, and hepatic steatosis (Foote et al., 2010; Parra et al., 2010). Thus, similarities appear in trans-10,cis-12 CLA investigations of MFD in ruminants and anti-obesity in rodents where specific reductions in fat synthesis occur at lower CLA doses but higher doses result in adverse performance effects that may involve inflammation and apoptosis.

\section{CONCLUSIONS}

Deleterious effects of a high dose of an unprotected CLA supplement on milk production and secretion of milk components in dairy ewes have not been previously reported. The decreased milk fat secretion in ewes fed CLA was accompanied by a lower proportion of short- and medium-chain FA and desaturase indexes in milk fat, which is, in turn, consistent with the inhibitory effect of trans-10, cis-12 CLA on de novo FA synthesis and desaturase activity observed in previous studies with dairy ewes and cows. However, the level of CLA supplementation also resulted in a relatively high concentration of trans-10, cis-12 CLA in milk fat, which corresponded to a decrease in the production of milk; significant decreases in the secretion of milk fat, lactose, and protein; and an increase in milk SCC. These offtarget responses are consistent with high doses of CLA, resulting in effects involving apoptosis and involution of mammary epithelial cells, as suggested in earlier work by Bell and Kennelly (2003).

\section{ACKNOWLEDGMENTS}

The authors gratefully acknowledge Ariovaldo Zanni for the donation of unprotected CLA by BASF AG (São Paulo, Brazil). The assistance of the following colleagues and undergraduate students from Santa Catarina State University is appreciated: Marcio Pereira Soares, Sérgio de Oliveira Juchem, Roberto Fornazier, Fábio Júnior Bianchett, Douglas Soster, Marcelo Girardi, Alexandre Bartsch, and Marcelise Regina Fachinelo. The authors also thank Ernando F. Motta, Fernando César Ferraz Lopes, and Hernani G. B. Filho from Embrapa Dairy Cattle (Juiz de Fora, Brazil) and Mariana Macedo Almeida from the Federal University of Juiz de Fora (Juiz de Fora, Brazil) for helping with the milk fatty acid profile analysis.

\section{REFERENCES}

AOAC. 2000. Official Methods of Analysis. 17th ed. Association of Official Analytical Chemists, Arlington, VA.

Bauman, D. E., K. J. Harvatine, and A. L. Lock. 2011. Nutrigenomics, rumen-derived bioactive fatty acids, and the regulation of milk fat synthesis. Annu. Rev. Nutr. 31:299-319.

Bauman, D. E. A. L. Lock, B. A. Corl, C. Ip, A. M. Salter, and P. W Parodi. 2006. Milk fatty acids and human health: Potential role of conjugated linoleic acid and trans fatty acids. Pages 529-561 in Ruminant Physiology: Digestion, Metabolism and Impact of Nutrition on Gene Expression, Immunology and Stress. K. Sejrsen, T. Hvelplund, and M. O. Nielson, ed. Wageningen Academic Publishers, Wageningen, the Netherlands.

Bauman, D. E., J. W. Perfield II, K. J. Harvatine, and L. H. Baumgard. 2008. Regulation of fat synthesis by CLA: Lactation and the ruminant model. J. Nutr. 138:403-409.

Baumgard, L. H., B. A. Corl, D. A. Dwyer, A. Saebø, and D. E. Bauman. 2000. Identification of the conjugated linoleic acid isomer 
that inhibits fat synthesis. Am. J. Physiol. Regul. Integr. Comp. Physiol. 278:R179-R184.

Baumgard, L. H., E. Matitashvili, B. A. Corl, D. A. Dwyer, and D. E. Bauman. 2002. Trans-10, cis-12 conjugated linoleic acid decreases lipogenic rates and expression of genes involved in milk lipid synthesis in dairy cows. J. Dairy Sci. 85:2155-2163.

Bell, J. A., and J. J. Kennelly. 2003. Postruminal infusion of conjugated linoleic acids negatively impacts milk synthesis in Holstein cows. J. Dairy Sci. 86:1321-1324.

Bernal-Santos, G., J. W. Perfield II, D. M. Barbano, D. E. Bauman, and T. R. Overton. 2003. Production responses of dairy cows to dietary supplementation with conjugated linoleic acid (CLA) during the transition period and early lactation. J. Dairy Sci. $86: 3218-3228$

Castañeda-Gutiérrez, E., B. C. Benefield, M. J. de Veth, N. R. Santos, R. O. Gilbert, W. R. Butler, and D. E. Bauman. 2007. Evaluation of the mechanism of action of conjugated linoleic acid isomers on reproduction in dairy cows. J. Dairy Sci. 90:4253-4264.

Chilliard, Y., A. Ferlay, J. Rouel, and G. Lamberet. 2003. A review of nutritional factors affecting goat milk lipid synthesis and lipolysis. J. Dairy Sci. 86:1751-1770.

Chouinard, P. Y., L. Corneau, D. M. Barbano, L. E. Metzger, and D. E. Bauman. 1999. Conjugated linoleic acids alter milk fatty acid composition and inhibit milk fat secretion in dairy cows. J. Nutr. 129:1579-1584.

Christie, W. W. 1982. A simple procedure for rapid transmethylation of glycerolipids and cholesterol esters. J. Lipid Res. 23:1072-1075.

Cruz-Hernandez, C., J. K. G. Kramer, J. J. Kennelly, D. R. Glimm, B. M. Sorensen, E. K. Okine, L. A. Goonewardene, and R. J. Weselake. 2007. Evaluating the conjugated linoleic acid and trans 18:1 isomers in milk fat of dairy cows fed increasing amounts of sunflower oil and a constant level of fish oil. J. Dairy Sci. 90:3786-3801.

de Veth, M. J., J. M. Griinari, A. M. Pfeiffer, and D. E. Bauman. 2004. Effect of CLA on milk fat synthesis in dairy cows: Comparison of inhibition by methyl esters and free fatty acids and relationships among studies. Lipids 39:365-372.

de Veth, M. J., E. Castañeda-Gutiérrez, D. A. Dwyer, A. M. Pfeiffer, D. E. Putnam, and D. E. Bauman. 2006. Response to conjugated linoleic acid in dairy cows differing in energy and protein status. J. Dairy Sci. 89:4620-4631.

Foote, M. R., S. L. Giesy, G. Bernal-Santos, D. E. Bauman, and Y. R. Boisclair. 2010. $t 10, c 12$-CLA decreases adiposity in peripubertal mice without dose-related detrimental effects on mammary development, inflammation status, and metabolism. Am. J. Physiol. Regul. Integr. Comp. Physiol. 299:R1521-R1528.

Gervais, R., J. W. McFadden, A. J. Lengi, B. A. Corl, and P. Y. Chouinard. 2009. Effects of intravenous infusion of trans-10, cis-12 18:2 on mammary lipid metabolism in lactating dairy cows. J. Dairy Sci. 92:5167-5177.

Hara, A., and N. S. Radin. 1978. Lipid extraction of tissues with lowtoxicity solvent. Anal. Biochem. 90:420-426.

Harvatine, K. J., and D. E. Bauman. 2006. SREBP1 and thyroid hormone responsive Spot 14 (S14) are involved in the regulation of bovine mammary lipid synthesis during diet-induced milk fat depression and treatment with CLA. J. Nutr. 136:2468-2474.

Harvatine, K. J., Y. R. Boisclair, and D. E. Bauman. 2009. Recent advances in the regulation of milk fat synthesis. Animal 3:40-54.

Jenkins, T. C., R. J. Wallace, P. J. Moate, and E. E. Mosley. 2008. Board-invited review: Recent advances in biohydrogenation of unsaturated fatty acids within the rumen microbial ecosystem. J. Anim. Sci. 86:397-412.

Keating, A. F., F.-Q. Zhao, K. A. Finucane, D. R. Glimm, and J. J. Kennelly. 2008. Effect of conjugated linoleic acid on bovine mammary cell growth, apoptosis and stearoyl Co-A desaturase gene expression. Domest. Anim. Endocrinol. 34:284-292.

Kennedy, A., K. Martinez, S. Schmidt, S. Mandrup, K. LaPoint, and M. McIntosh. 2010. Antiobesity mechanisms of action of conjugated linoleic acid. J. Nutr. Biochem. 21:171-179.
Kramer, J. K. G., C. Cruz-Hernandez, and J. Zhou. 2001. Conjugated linoleic acids and octadecenoic acids: Analysis by GC. Eur. J. Lipid Sci. Technol. 103:600-609.

Kuehl, R. O. 2000. Design of Experiments: Statistical Principles of Research Design and Analysis. 2nd ed. Duxbury Press, New York, NY

Lock, A. L., and D. E. Bauman. 2004. Modifying milk fat composition of dairy cows to enhance fatty acids beneficial to human health. Lipids 39:1197-1206.

Lock, A. L., M. Rovai, T. A. Gipson, M. J. de Veth, and D. E. Bauman. 2008. A conjugated linoleic acid supplement containing trans-10, cis-12 conjugated linoleic acid reduces milk fat synthesis in lactating goats. J. Dairy Sci. 91:3291-3299.

Lock, A. L., B. M. Teles, J. W. Perfield II, D. E. Bauman, and L. A. Sinclair. 2006. A conjugated linoleic acid supplement containing trans-10, cis-12 reduces milk fat synthesis in lactating sheep. J. Dairy Sci. 89:1525-1532.

Mackle, T. R., J. K. Kay, M. J. Auldist, A. K. H. McGibbon, B. A. Philpott, L. H. Baumgard, and D. E. Bauman. 2003. Effects of abomasal infusion of conjugated linoleic acid on milk fat concentration and yield from pasture-fed dairy cows. J. Dairy Sci. $86: 644-652$.

Maia, M. R. G., L. C. Chaudhary, C. S. Bestwick, A. J. Richardson, N. McKain, T. R. Larson, I. A. Graham, and R. J. Wallace. 2010 Toxicity of unsaturated fatty acids to the biohydrogenating ruminal bacterium, Butyrivibrio fibrisolvens. BMC Microbiol. 10:52. doi:10.1186/1471-2180-10-52.

Medeiros, S. R., D. E. Oliveira, L. J. M. Aroeira, M. A. McGuire, D. E. Bauman, and D. P. D. Lanna. 2010. Effects of dietary supplementation of rumen-protected conjugated linoleic acid to grazing cows in early lactation. J. Dairy Sci. 93:1126-1137.

NRC. 2007. Nutrient Requirements of Small Ruminants: Sheep, Goats, Cervids, and New World Camelids. 1st ed. National Academy Press, Washington, DC.

Odens, L. J., R. Burgos, M. Innocenti, M. J. VanBaale, and L. H. Baumgard. 2007. Effects of varying doses of supplemental conjugated linoleic acid on production and energetic variables during the transition period. J. Dairy Sci. 90:293-305.

Parodi, P. W. 1997. Cows' milk fat components as potential anticarcinogenic agents. J. Nutr. 127:1055-1060.

Parra, P., F. Serra, and A. Palou. 2010. Moderate doses of conjugated linoleic acid isomers mix contribute to lowering body fat content maintaining insulin sensitivity and a noninflammatory pattern in adipose tissue in mice. J. Nutr. Biochem. 21:107-115.

Perfield, J. W. II, A. L. Lock, A. M. Pfeiffer, and D. E. Bauman. 2004 Effects of amide-protected and lipid-encapsulated conjugated linoleic acid (CLA) supplements on milk fat synthesis. J. Dairy Sci. 87:3010-3016.

Poirier, H., J. S. Shapiro, R. J. Kim, and M. A. Lazar. 2006. Nutritional supplementation with trans-10, cis-12 conjugated linoleic acid induces inflammation of white adipose tissue. Diabetes $55: 1634-1641$.

Sæbø, A. 2003. Commercial synthesis of conjugated linoleic acid. Pages 71-81 in Advances in Conjugated Linoleic Acid Research. J.-L. Sébédio, W. W. Christie, and R. O. Adlof, ed. AOCS Press, Champaign, IL.

Shingfield, K. J., L. Bernard, C. Leroux, and Y. Chilliard. 2010. Role of trans fatty acids in the nutritional regulation of mammary lipogenesis in ruminants. Animal 4:1140-1166.

Shingfield, K. J., J. Rouel, and Y. Chilliard. 2009. Effect of calcium salts of a mixture of conjugated linoleic acids containing trans-10, cis-12 in the diet on milk fat synthesis in goats. Br. J. Nutr. 101:1006-1019.

Sinclair, L. A., A. L. Lock, R. Early, and D. E. Bauman. 2007. Effects of trans-10, cis-12 conjugated linoleic acid on ovine milk fat synthesis and cheese properties. J. Dairy Sci. 90:3326-3335.

Sinclair, L. A., M. Weerasinghe, P. B. Weerasinghe, R. G. Wilkinson, M. J. de Veth, and D. E. Bauman. 2010. A supplement containing trans-10, cis-12 conjugated linoleic acid reduces milk fat yield but 
does not alter organ weight or body fat deposition in lactating ewes. J. Nutr. 140:1949-1955.

Tedeschi, L. O., A. Cannas, and D. G. Fox. 2010. A nutrition mathematical model to account for dietary supply and requirements of energy and other nutrients for domesticated small ruminants: The development and evaluation of the Small Ruminant Nutrition System. Small Rumin. Res. 89:174-184.

Tsuboyama-Kasaoka, N., M. Takahashi, K. Tanemura, H. J. Kim, T. Tange, H. Okuyama, M. Kasai, S. Ikemoto, and O. Ezaki. 2000 Conjugated linoleic acid supplementation reduces adipose tis- sue by apoptosis and develops lipodystrophy in mice. Diabetes 49:1534-1542.

Van Soest, P. J., J. B. Robertson, and B. A. Lewis. 1991. Methods for dietary fiber, neutral detergent fiber, and nonstarch polysaccharides in relation to animal nutrition. J. Dairy Sci. 74:3583-3597. von Soosten, D., U. Meyer, E. M. Weber, J. Rehage, G. Flachowsky, and S. Dänicke. 2011. Effect of trans-10, cis-12 conjugated linoleic acid on performance, adipose depot weights, and liver weight in early-lactation dairy cows. J. Dairy Sci. 94:2859-2870. 